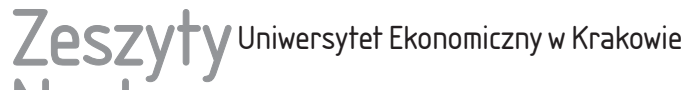 Naukowe
}

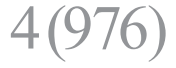

ISSN 1898-6447

e-ISSN 2545-3238

Zesz. Nauk. UEK, 2018; 4 (976): 219-235

https://doi.org/10.15678/ZNUEK.2018.0976.0413

Mariusz Grabowski

Jan Madej

Jan Trąbka

\section{Koncepcja metodyki projektowania i wdrażania dobrych praktyk informatycznych dla sądów powszechnych $^{*}$}

\section{Streszczenie}

W artykule przedstawiono proces opracowania koncepcji i wdrożenia dobrych praktyk informatycznych, które powstały podczas realizacji projektu „PWP Edukacja w dziedzinie zarządzania czasem i kosztami postępowań sądowych - case management" (w ramach programu operacyjnego „Kapitał ludzki”). Projekt ten był jednym z elementów wspierających reformę polskiego wymiaru sprawiedliwości i miał na celu podniesienie efektywności procesu orzecznictwa sądów poprzez skrócenie jego czasu, zmniejszenie kosztów oraz podniesienie kwalifikacji pracowników sądownictwa. Opisano wszystkie etapy, w których brali udział autorzy (zaangażowani w realizacji projektu jako eksperci, a zarazem pracownicy naukowi), od zapoznania się z autodiagnozą 30 sądów pilotażowych, poprzez prze-

Mariusz Grabowski, Uniwersytet Ekonomiczny w Krakowie, Wydział Zarządzania, Katedra Systemów Obliczeniowych, ul. Rakowicka 27,31-510 Kraków, e-mail: grabowsm@uek.krakow.pl Jan Madej, Uniwersytet Ekonomiczny w Krakowie, Wydział Zarządzania, Katedra Informatyki, ul. Rakowicka 27, 31-510 Kraków, e-mail: madejj@uek.krakow.pl

Jan Trąbka, Uniwersytet Ekonomiczny w Krakowie, Wydział Zarządzania, Katedra Informatyki, ul. Rakowicka 27, 31-510 Kraków, e-mail: trabkaj@uek.krakow.pl

* Artykuł powstał w wyniku prac nad projektem pt. „PWP Edukacja w dziedzinie zarządzania czasem i kosztami postępowań sądowych - case management”, nr projektu POKL.05.03.00-00-012/11. 
prowadzenie wizyt w sądach, aż do przygotowania ostatecznej koncepcji i wdrożenia sześciu dobrych praktyk informatycznych w 60 sądach.

Słowa kluczowe: technologia informatyczna, system informatyczny, dobre praktyki informatyczne, wymiar sprawiedliwości, sądy, efektywność orzecznictwa.

Klasyfikacja JEL: M15, K00.

\section{Wprowadzenie}

Celem artykułu jest przedstawienie koncepcji projektowania i wdrażania dobrych praktyk informatycznych dla sądów powszechnych, które powstały podczas wdrażania pilotażu dobrego zarządzania jednostkami wymiaru sprawiedliwości w ramach projektu „PWP Edukacja w dziedzinie zarządzania czasem i kosztami postępowań sądowych - case management" programu operacyjnego „Kapitał ludzki”, oraz charakterystyka otoczenia i uwarunkowań związanych $\mathrm{z}$ realizacją tego typu projektu.

W latach 2013-2014 autorzy artykułu wchodzili w skład zespołu ekspertów zajmującego się opracowaniem koncepcji dobrych praktyk informatycznych, które następnie zostały zaoferowane do wdrożenia w 60 sądach różnych szczebli. Wdrażanie praktyk trwało do końca 2014 r., a w 2015 r. opracowane zostały raporty podsumowujące projekt oraz przeprowadzone badania ewaluacyjne wdrożenia. Powstały także publikacje, w których przedstawiono studium przypadku, zakres prac oraz możliwości wykorzystania narzędzi IT w sądownictwie (Grabowski, Madej i Trąbka 2014a, b, Grabowski 2015).

Na wstępie należy zaznaczyć, że dużym problemem wdrożeniowym i zarazem bardzo ciekawym problemem badawczym było zaproponowanie i wdrożenie rozwiązania z obszaru biznesu i działalności gospodarczej w tak nietypowej organizacji, jaką są sądy. Okazały się one specyficznymi organizacjami podlegającymi wielu regulacjom prawnym. Ich charakter odbiega od rozwiązań rynkowych, bardzo duże znaczenie ma w nich formalna i nieformalna struktura zależności oraz niezawisłość sędziowska postrzegana w skrajnym przypadku nawet jako niezależność od funkcjonujących w sądzie rozwiązań informatycznych.

Dużym wyzwaniem stał się wybór dobrych praktyk. Rozmowy, które podczas wizyt przeprowadził zespół ze służbami informatycznymi sądów, potwierdziły złożoną sytuację w tym zakresie i bardzo zróżnicowany poziom informatyzacji sądów oraz wskazały trudności z bezpośrednim zastosowaniem wielu rozwiązań informatycznych funkcjonujących w biznesie.

Analiza literatury zagranicznej wykazała także, że badania w tym zakresie nie są częste i odnoszą się do fragmentarycznych rozwiązań dostosowanych zwykle do specyfiki prawodawstwa danego kraju, np. klasyfikowanie petycji sądowych 
w sprawie e-sądu (Bueno i in. 2003), wprowadzanie cyfrowego powiadomienia o dokumentach sądowych (Luzuriaga i Cechich 2011), lub do wprowadzania usprawnień informatycznych na jednym z poziomów sądu (Gorham 2012) lub w krajowym systemie wymiaru sprawiedliwości (Andrade i Joia 2010). W literaturze polskiej M. Rojewski (2012) opisuje wdrożenie systemów Krajowego Rejestru Sądowego oraz ksiąg wieczystych i podkreśla, że projekt ten jest największym osiągnięciem polskiego wymiaru sprawiedliwości w XXI w., a należy zauważyć, że system ten jest raczej rodzajem centralnej ewidencji niż systemem wspierającym zarządzanie sprawami w jednostkach sądowych. Znacznie więcej publikacji na temat informatyzacji sądownictwa można było znaleźć w zakresie dziedzin prawniczych. Na przykład J. Gołaczyński (2009) przedstawił uwzględnienie informatyzacji w rozwoju sądownictwa krajów UE, pozostałych państw europejskich oraz Stanów Zjednoczonych. Autor podał wiele przykładów rozwiązań legislacyjno-technicznych funkcjonujących w innych krajach, a niedostępnych w Polsce. Z kolei autorzy pracy pt. Informatyzacja postępowania cywilnego. Teoria i praktyka (2016, s. 9) wskazują przemiany prawa wywołane stosowaniem narzędzi informatycznych na przykładzie prawa cywilnego procesowego, konstatując, że ,technologie informatyczne stanowią naturalne narzędzie usprawnienia działalności sądów w niewyobrażalnej dotąd skali zarówno w sferze szybkości postępowania, jak i jego jakości. Powstaje jedynie pytanie, w jakim tempie i przy jakich przeszkodach technicznych, organizacyjnych i mentalnych uda się wdrożyć jak najszerzej rozwiązania wykorzystujące ogromne zasoby możliwości tkwiących w procesie informatyzacji”. Nieliczne prace naukowe i wdrożeniowe oraz cytowany wniosek potwierdzają istnienie luki badawczej i wyzwanie, przed którym stanęli autorzy niniejszego artykułu.

\section{Uwarunkowania i otoczenie projektu}

Projekt „PWP Edukacja w dziedzinie zarządzania czasem i kosztami...” był jednym z elementów wspierających reformę polskiego wymiaru sprawiedliwości, której celem jest podnoszenie efektywności działalności orzeczniczej sądów, zmniejszenie kosztów tej działalności oraz podniesienie kwalifikacji pracowników sądownictwa. W realizacji projektów tego typu Ministerstwo Sprawiedliwości oraz jednostki podległe, w tym Krajowa Szkoła Sądownictwa i Prokuratury (KSSiP), korzystają ze środków unijnych m.in. Europejskiego Funduszu Społecznego, w ramach programu operacyjnego „Kapitał ludzki”, a w jego ramach z osi priorytetów „V. Dobre rządzenie”, których celem jest podniesienie potencjału administracji i wymiaru sprawiedliwości w obszarze stanowienia prawa oraz wzmacniania zdolności do świadczenia wysokiej jakości usług. W ramach działania 5.3 celem szczegółowym jest wzmocnienie mechanizmów kreowania i wdrażania polityki 
publicznej, stanowienia prawa oraz poprawa jakości usług świadczonych przez wymiar sprawiedliwości (Działanie 5.3... 2016). W obszarze tych działań KSSiP realizowała serię projektów, których celem było wzmocnienie i rozwój potencjału wymiaru sprawiedliwości m.in. poprzez modernizację systemu zarządzania oraz organizacji pracy w sądownictwie, wzrost efektywności mechanizmów konsultacyjnych i współpracy z partnerami społecznymi, popularyzację europejskich standardów sprawności postępowań (Czapracka, Rostkowski i Witkowski 2015).

W ramach omawianego projektu wyznaczono m.in. pilotaż wdrażania nowoczesnych metod zarządzania sądami, pilotaż wdrażania efektywnych metod zarządzania sprawą, podnoszenie kwalifikacji pracowników wymiaru sprawiedliwości poprzez szkolenia e-learningowe (Materiały przetargowe... 2013).

W ramach przetargu konsorcjum, w skład którego weszły Uniwersytet Ekonomiczny w Krakowie, Instytut Allerhanda w Krakowie oraz firmy doradcze PSDB Sp. z o.o. i WYG Consulting Sp. z o.o., objęło realizację części prac z zadania „pilotażowego wdrażania nowoczesnych metod zarządzania sądami”. Do realizacji przez konsorcjum zostały przewidziane następujące prace:

- szkolenia z zakresu nowoczesnych kadr i finansów w sądzie,

- szkolenia z zakresu zarządzania przepływem spraw i obciążeniem pracą w wydziale,

- szkolenia z zakresu zarządzania zasobami ludzkimi i zastosowania nowoczesnych technologii,

- sporządzenie raportu wstępnie diagnozującego sytuację w 30 sądach pilotażowych oraz wskazującego planowane główne kierunki działań (opracowanie wstępnej listy dobrych praktyk), a następnie opracowanie koncepcji 20 dobrych praktyk z zakresu zarządzania oraz wdrożenie po 15 z nich w każdym z 30 sądów.

W próbie 30 sądów pilotażowych znajdowały się: 1 sąd apelacyjny, 8 sądów okręgowych, 21 sądów rejonowych ${ }^{1}$.

Autorzy należeli do grupy ekspertów, której celem było przygotowanie wstępnych oraz pełnych koncepcji dobrych praktyk, które następnie były wdrażane przez zespoły pozostałych konsorcjantów. W skład grupy ekspertów wchodzili eksperci z zakresu zarządzania personelem, organizacji i zarządzania oraz IT. Obszary badania dobrych praktyk podzielone zostały na organizacyjno-zarządcze oraz informatyczne. Autorzy utworzyli Zespół ds. IT i odpowiadali za przygotowanie koncepcji 6 praktyk z obszaru informatyki.

1 Zgodnie z art. 175 ust. 1 Konstytucji RP wymiar sprawiedliwości w Polsce sprawują: Sąd Najwyższy, sądy powszechne, sądy administracyjne oraz sądy wojskowe. Sądownictwo powszechne składa się z trzech szczebli: sądów rejonowych, okręgowych i apelacyjnych. W momencie realizacji projektu w Polsce było 321 sądów rejonowych, 45 sądów okręgowych, 11 sądów apelacyjnych. Sądami kierują prezesi powoływani przez Ministra Sprawiedliwości oraz w zakresie finansowym i gospodarczym dyrektorzy sądów apelacyjnych i okręgowych oraz kierownicy finansowi sądów rejonowych. 


\section{Metodyka oraz narzędzia projektowania i wdrożenia dobrych praktyk informatycznych dla sądów powszechnych}

Ze względu na specyficzny charakter organizacji, jakimi są sądy, wybór dobrych praktyk okazał się trudny, a dodatkowo, podczas spotkań z osobami kierującymi sądami (prezesami, dyrektorami i kierownikami), często wychodziły na jaw ich rozbieżne oczekiwania co do informatyzacji sądów. W związku z tym członkowie zespołu postanowili wykorzystać podejście prezentowane w metodach badawczych action research (AR), czyli uznali, że najwyższe kompetencje do rozumienia zasad funkcjonowania sądów mają ich pracownicy, więc zamiast narzucać im gotowe i sprawdzone rozwiązania, próbowali zrozumieć ich sposób postrzegania sądów i pomóc w poradzeniu sobie z problemami zgodnie z ich oczekiwaniami. Action research (badania w działaniu) wykorzystywane jest właśnie w kontekście odkrywania teorii potrzebnej do rozwiązywania problemów praktycznych i pozwala m.in. na lepsze zrozumienie złożonego zjawiska poprzez wspólne prowadzenie badań (przez badacza i badane podmioty) oraz równoczesne rozwiązywanie problemów i zdobywanie wiedzy naukowej, którą można natychmiast zastosować (Baskerville i Wood-Harper 1996, Baskerville 1999). Należy zaznaczyć, że pomimo iż AR wywodzi się z nauk społecznych, a niektórzy naukowcy krytykowali je za brak rygoru naukowego oraz trudności w rozróżnieniu pomiędzy AR a konsultingiem (Davison, Martinsons i Kock 2004), to okazało się ono skuteczne w dyscyplinie systemów informacyjnych i obecnie wraz z podejściem opartym na studiach przypadku należy do głównego nurtu badań w interpretacyjnym paradygmacie metodologicznym w SI (Cole i Avison 2007). Jednakże na skutek krytyki opracowano bardziej zaawansowany typ AR, czyli cannonical action research (CAR), który jest rygorystycznym, opartym na współpracy i iteracyjnym procesem badawczym składającym się z pięciu etapów: diagnozy, planowania, interwencji, oceny i refleksji (Davison, Martinsons i Kock 2004, Davison, Martinsons i Ou 2012, Vries 2007).

Podejście AR w pracy zespołu oznaczało, że zaproponowane koncepcje dobrych praktyk powstały w wyniku obserwacji rozwiązań stosowanych w sądach i współpracy z pracownikami sądu lub wynikały z potrzeb przez nich zgłaszanych.

Najważniejsze etapy prac Zespołu ds. IT nad opracowaniem i wdrożeniem dobrych praktyk przedstawione zostały na rys. 1 .

Sądy uczestniczące w projekcie już w 2011 r. przeprowadziły autodiagnozę, w której zidentyfikowały najważniejsze problemy związane $\mathrm{z}$ ich funkcjonowaniem, wskazały braki w zakresie konkretnych rozwiązań i narzędzi oraz wyraziły zainteresowanie ich opracowaniem i wdrożeniem. Ponadto niektóre sądy informowały o już istniejących rozwiązaniach (swoich mocnych stronach oraz dobrych 
praktykach), które - według nich - sprawdzają się w organizacji i zasługują na rozpropagowanie w innych sądach.

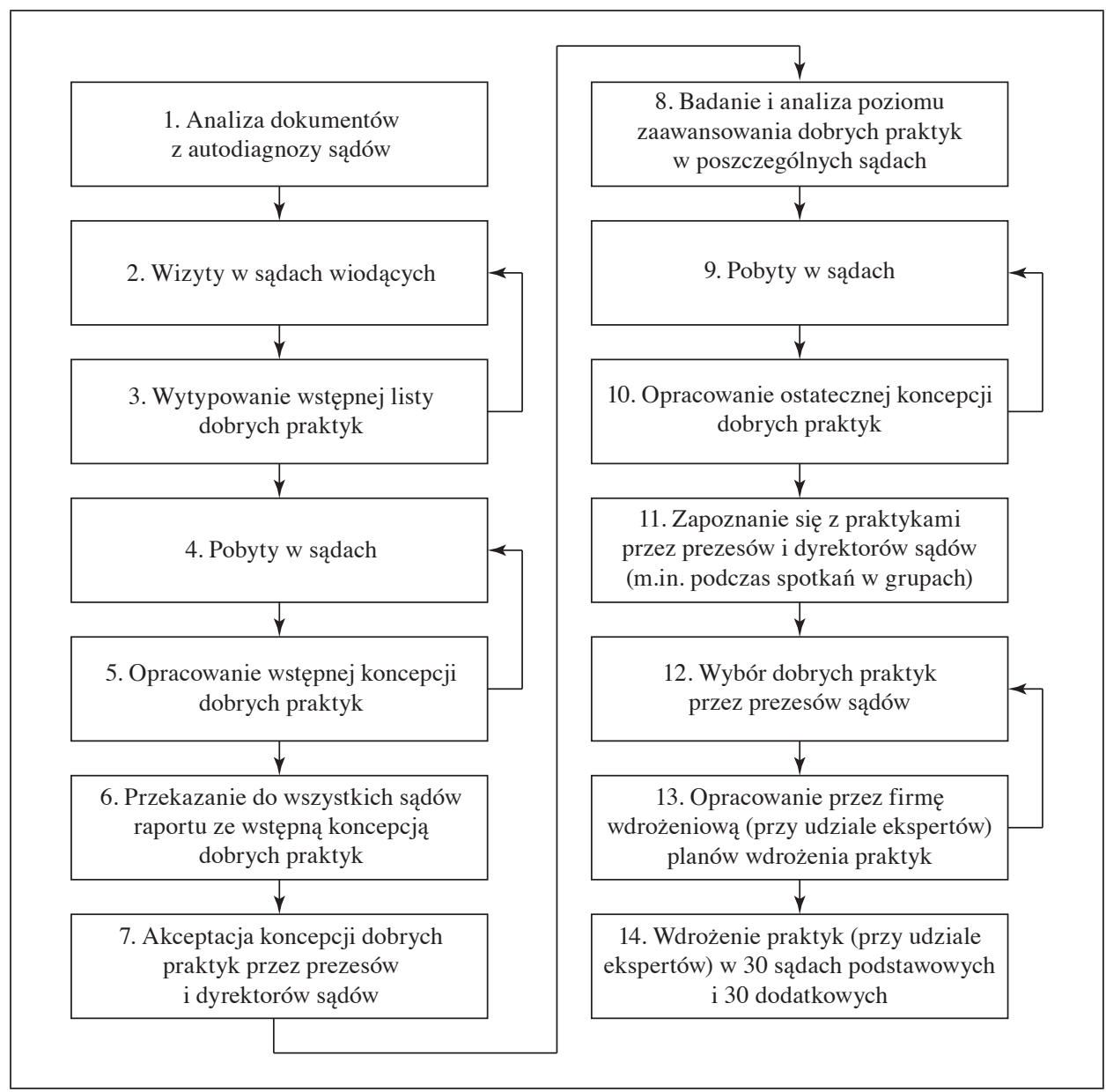

Rys. 1. Metodyka projektowania i wdrożenia dobrych praktyk dla sądów powszechnych Źródło: opracowanie własne.

Dokumenty autodiagnozy stały się punktem wyjścia do prac ekspertów, w tym także Zespołu ds. IT (rys. 1, etap 1). Podczas analizy tych dokumentów udało się wyodrębnić zagadnienia związane z zarządzaniem personelem, organizacją pracy, komunikacją wewnętrzną i zewnętrzną oraz obiegiem informacji.

Po analizie dokumentów autodiagnozy odbyły się wizyty w tzw. sądach wiodących (rys. 1, etap 2), które eksperci roboczo nazwali sądami o wyższym niż 
przeciętny poziomie zaawansowania i wykorzystania technik i narzędzi z zakresu HR, organizacji i zarządzania oraz IT. Wizyty miały na celu m.in. skonsultowanie stanu rzeczywistego ze stanem przedstawionym w autodiagnozie oraz identyfikację funkcjonujących w sądach dobrych praktyk. W wizytach uczestniczyli eksperci z wszystkich dziedzin, prezesi i dyrektorzy sądów oraz kierownicy i pracownicy działu kadr, księgowości i działu IT. Omawiano zgłoszone przez sądy problemy, prezentowano - w ogólnym zarysie - funkcjonujące praktyki oraz przedstawiano uwagi i propozycje ekspertów. Na skutek przeprowadzonych wizyt Zespół ds. IT określił kierunki badań, zaplanował dalsze prace oraz wytypował wstępną listę dobrych praktyk (rys. 1, etap 3).

Dalsze prace Zespołu ds. IT przeprowadzane były podczas tzw. pobytów w sądach (rys. 1, etap 4). Odbywały się one w siedzibie sądu i miały charakter spotkań roboczych, w których uczestniczyli członkowie zespołu oraz pracownicy działu IT. Zespół zapoznawał się z funkcjonującymi w sądzie dobrymi praktykami oraz prezentował dobre praktyki z innych sądów. Bezpośrednie spotkania zespołu z pracownikami sądu pozwoliły na wzajemną wymianę informacji w obszarze funkcjonujących już praktyk oraz zaowocowały pomysłami na ich udoskonalenie.

Po odbyciu wielu spotkań Zespół ds. IT wytypował i opracował wstępną koncepcję siedmiu dobrych praktyk (rys. 1, etap 5):

- informatyczny system rezerwacji zasobów,

- audyt bezpieczeństwa systemów informatycznych,

- zarządzanie obiegiem akt sądowych,

- zarządzanie aktami sądowymi w postaci cyfrowej,

- zarządzanie zasobami i usługami informatycznymi,

- „eNakaz” - elektroniczny nakaz doprowadzenia,

- informatyczne narzędzia komunikacji wewnętrznej.

Jednak już na tym etapie okazało się, że niektóre wytypowane praktyki występują w sądach na różnym poziomie lub pracownicy sądów oczekują ich wdrożenia w różnym stopniu. To wymaganie sprawiło, że konieczne stało się wyróżnienie kilku poziomów realizacji dobrych praktyk, aby zaspokoić oczekiwania pracowników sądów. Członkowie zespołu nawiązali więc do koncepcji poziomów dojrzałości systemu, której istotą jest przyporządkowanie określonemu procesowi odpowiedniego poziomu dojrzałości odzwierciedlającego zdolność jednostki do prowadzenia właściwych działań oraz osiągania doskonałości procesowej (Paulk i in. 1993). Dla każdej praktyki wyróżnione zostało pięć poziomów dojrzałości nawiązujących do standardu COBIT (COBIT 4.1... 2010) i ułatwiających późniejsze dopasowanie konkretnej praktyki do potrzeb danego sądu. Krótka charakterystyka koncepcji poszczególnych praktyk znajduje się w tabelach 1-7. 
Tabela 1. Informatyczny system rezerwacji zasobów

\begin{tabular}{|c|l|}
\hline Poziom & \multicolumn{1}{|c|}{ Charakterystyka } \\
\hline I & $\begin{array}{l}\text { Lokalne aplikacje (np. odpowiednio opracowane arkusze kalkulacyjne) wykorzysty- } \\
\text { wane przez poszczególne jednostki sądu służące do rezerwacji zasobów }\end{array}$ \\
\hline II & $\begin{array}{l}\text { Sieciowa, scentralizowana aplikacja do rezerwacji zasobów materialnych (sale rozpraw, } \\
\text { sale konferencyjne, ,błękitny pokój”, samochody, notebooki, projektory itd.) }\end{array}$ \\
\hline III & $\begin{array}{l}\text { Poziom II oraz kalendarz prezesa sądu, dyrektora i innych osób na kierowniczych } \\
\text { stanowiskach }\end{array}$ \\
\hline IV & $\begin{array}{l}\text { Poziom III oraz sformalizowana metoda rezerwacji zasobów oraz mierniki ich wyko- } \\
\text { rzystania }\end{array}$ \\
V & $\begin{array}{l}\text { Poziom IV oraz analiza trendów (obciążenia wykorzystywania zasobów), analiza } \\
\text { potrzeb użytkowników w zakresie rezerwacji zasobów, modyfikacja modelu rezerwacji }\end{array}$ \\
\hline
\end{tabular}

Źródło: opracowanie własne.

Tabela 2. Audyt bezpieczeństwa systemów informatycznych

\begin{tabular}{|c|l|}
\hline Poziom & \multicolumn{1}{|c|}{ Charakterystyka } \\
\hline I & $\begin{array}{l}\text { Audyt informatyczny (z wykorzystaniem list kontrolnych) na poziomie poszczególnych } \\
\text { stanowisk komputerowych oraz analiza uzyskanych wyników }\end{array}$ \\
\hline II & $\begin{array}{l}\text { Poziom I oraz audyt informatyczny (z wykorzystaniem list kontrolnych) na poziomie } \\
\text { poszczególnych systemów informatycznych oraz analiza uzyskanych wyników }\end{array}$ \\
\hline III & $\begin{array}{l}\text { Poziom II oraz opracowanie sformalizowanej metody oceny i analizy zawartości list } \\
\text { kontrolnych pozwalającej na aktualizację i modyfikację list }\end{array}$ \\
\hline IV & $\begin{array}{l}\text { Poziom III oraz stworzenie forum bezpieczeństwa aktywnie zajmującego się problema- } \\
\text { tyką bezpieczeństwa systemów informatycznych }\end{array}$ \\
\hline V & Poziom IV oraz śledzenie zagrożeń oraz trendów w zakresie zabezpieczeń \\
\hline
\end{tabular}

Źródło: opracowanie własne.

Tabela 3. Zarządzanie obiegiem akt sądowych

\begin{tabular}{|c|l|}
\hline Poziom & \multicolumn{1}{|c|}{ Charakterystyka } \\
\hline I & $\begin{array}{l}\text { System zarządzania aktami na poziomie sekretariatów (nadawanie i rejestrowanie } \\
\text { kodów kreskowych dla poszczególnych tomów akt) }\end{array}$ \\
\hline II & $\begin{array}{l}\text { Poziom I oraz system zarządzania aktami w archiwum } \\
\text { III }\end{array}$ \\
$\begin{array}{l}\text { Poziom II oraz narzędzia wspomagające przekazywanie akt do archiwum państwo- } \\
\text { wego (dane w formacie XML) }\end{array}$ \\
\hline IV & Poziom III oraz system lokalizacji akt \\
\hline V & Poziom IV oraz wykorzystanie technologii radiowych do oznaczania i lokalizowania akt \\
\hline
\end{tabular}

Źródło: opracowanie własne. 
Tabela 4. Zarządzanie aktami sądowymi w postaci cyfrowej

\begin{tabular}{|c|l|}
\hline Poziom & \multicolumn{1}{|c|}{ Charakterystyka } \\
\hline I & Digitalizacja akt wielotomowych \\
\hline II & Bieżąca digitalizacja wszystkich akt \\
\hline III & Poziom II oraz uzyskiwanie akt „zewnętrznych” (np. od prokuratury) w postaci cyfrowej \\
\hline IV & $\begin{array}{l}\text { Poziom III oraz opracowanie sformalizowanego modelu udostępniania akt cyfrowych } \\
\text { oraz obliczanie metryk (np. akta cyfrowe/do normalnych; poziom wykorzystania akt) }\end{array}$ \\
\hline V & Poziom IV oraz śledzenie trendów w zakresie możliwości digitalizacji akt \\
\hline
\end{tabular}

Źródło: opracowanie własne.

Tabela 5. Zarządzanie zasobami i usługami informatycznymi

\begin{tabular}{|c|l|}
\hline Poziom & \multicolumn{1}{|c|}{ Charakterystyka } \\
\hline I & $\begin{array}{l}\text { Unifikacja sprzętu komputerowego - komputerów stacjonarnych, przenośnych, } \\
\text { serwerów, drukarek itd. (ustalenie parametrów urządzeń dla grup użytkowników) } \\
\text { oraz ustalanie odpowiedniej wielkości zamówienia }\end{array}$ \\
\hline II & $\begin{array}{l}\text { Poziom I oraz unifikacja typów sprzętu w modelu usługowym (np. komputer do } \\
\text { obsługi sekretariatu, komputer do obsługi sali rozpraw). Wykorzystanie list kontrol- } \\
\text { nych przy konfiguracji urządzeń i instalacji oprogramowania }\end{array}$ \\
\hline III & $\begin{array}{l}\text { Poziom II oraz automatyzacja instalacji i konfiguracji oprogramowania (wykorzystanie } \\
\text { np. Windows Deployment Services - WDS, Group Policy Objects - GPO) }\end{array}$ \\
\hline IV & $\begin{array}{l}\text { Poziom III oraz wykorzystanie narzędzi do opisu struktury informatycznej (np. Wiki- } \\
\text { Media, nVision, ADOit) }\end{array}$ \\
\hline V & $\begin{array}{l}\text { Poziom IV oraz implementacja elementów Information Technology Infrastructure } \\
\text { Library (ITIL) w zakresie świadczenia usług informatycznych. Helpdesk }\end{array}$ \\
\hline
\end{tabular}

Źródło: opracowanie własne.

Tabela 6. „eNakaz” - elektroniczny nakaz doprowadzenia

\begin{tabular}{|c|l|}
\hline Poziom & \multicolumn{1}{|c|}{ Charakterystyka } \\
\hline I & $\begin{array}{l}\text { Wykorzystanie szablonów pism wraz z danymi z systemu komputerowego (np. SAWA) } \\
\text { i wysyłanie ich tradycyjną pocztą }\end{array}$ \\
\hline II & $\begin{array}{l}\text { Poziom I oraz równoległe wysyłanie danych (np. w formacie XML) pocztą elektro- } \\
\text { niczną, dzięki czemu pracownicy policji nie muszą przepisy wać danych, gdyż dyspo- } \\
\text { nują oprogramowaniem do ich wczytywania }\end{array}$ \\
\hline III & $\begin{array}{l}\text { Poziom II oraz dedykowany program wyciągający dane z SAWA, zapis w XML, } \\
\text { szyfrowanie, ręczne wysyłanie pocztą elektroniczną i okresowa wymiana kluczy } \\
\text { pocztą elektroniczną }\end{array}$ \\
\hline IV & $\begin{array}{l}\text { Poziom III realizowany przez oprogramowanie wykorzystujące bezpośrednio zaszyfro- } \\
\text { wane połączenie sieciowe między sądem a policją (wyeliminowanie poczty elektro- } \\
\text { nicznej iłatwienie wymiany kluczy szyfrowania) }\end{array}$ \\
\hline V & Poziom IV oraz rozszerzenie systemu na służby więzienne \\
\hline
\end{tabular}

Źródło: opracowanie własne. 
Tabela 7. Informatyczne narzędzia komunikacji wewnętrznej

\begin{tabular}{|c|l|}
\hline Poziom & \multicolumn{1}{|c|}{ Charakterystyka } \\
\hline I & Wewnętrzny portal pracowniczy (udostępnianie komunikatów, plików itd.) \\
\hline II & Poziom I oraz wewnętrzna poczta elektroniczna \\
\hline III & Poziom II oraz komunikator i forum internetowe \\
\hline IV & $\begin{array}{l}\text { Poziom III oraz opracowanie formalnego modelu komunikacji (zasady przekazywania } \\
\text { danych, podpisy cyfrowe, zasady porządkowania i archiwizowania danych itd.) }\end{array}$ \\
\hline V & $\begin{array}{l}\text { Poziom IV oraz śledzenie procesu (np. w celu wyszukiwania wąskich gardeł), modyfi- } \\
\text { kowanie modelu komunikacji, badanie trendów w zakresie komunikacji elektronicznej } \\
\text { pod kątem ich wykorzystania w sądzie }\end{array}$ \\
\hline
\end{tabular}

Źródło: opracowanie własne.

Opracowane przez zespół koncepcje dobrych praktyk były konsultowane podczas kolejnych wizyt w sądach (rys. 1, etapy 4-5) nie tylko w tych, z których został zaczerpnięty pomysł dobrej praktyki, ale także w sądach, które danej praktyki nie stosowały. Celem spotkań było uzyskanie opinii na temat samej dobrej praktyki i opinii odnośnie do propozycji jej rozwoju i udoskonalenia. Równocześnie liczba praktyk została zredukowana do sześciu (usunięto praktykę „Zarządzanie obiegiem akt sądowych”). Podczas kolejnych spotkań i modyfikacji koncepcji dobrych praktyk udało się uzyskać pozytywne opinie pracowników działów IT na temat ich przydatności. Po zakończeniu pobytów w sądach zespół opracował swoją część raportu i przygotował prezentację dobrych praktyk na spotkanie z prezesami i dyrektorami sądów. Oprócz sześciu praktyk informatycznych pozostali eksperci opracowali 14 praktyk o charakterze organizacyjno-zarządczym.

Raport zawierający opis 20 praktyk został wysłany do sądów, a na spotkaniu z prezesami i dyrektorami sądów przedstawione i dyskutowane były różne aspekty związane $\mathrm{z}$ ich funkcjonowaniem i wpływem na organizację pracy sądów. Ostatecznie zaakceptowano przedstawione koncepcje praktyk (rys. 1, etap 7), a prezesi wyrazili chęć zapoznania się ze szczegółowym ich opisem. Warunki realizacji projektu wymagały także przeprowadzenia analizy stanu zaawansowania poszczególnych sądów (rys. 1, etap 8), dlatego do wszystkich sądów rozesłane zostały arkusze diagnostyczne z pytaniami o poziomy zaawansowania praktyk oraz o to, którymi praktykami sąd jest zainteresowany. Otrzymane wypełnione arkusze diagnostyczne wraz z uwagami do poszczególnych praktyk po przeprowadzonej analizie pozwoliły na lepsze dopasowanie koncepcji praktyk do potrzeb sądów.

Zespół ds. IT, na podstawie analizy stopnia zaawansowania, potrzeb i uwag sądów, ustalił harmonogram działań niezbędnych do opracowania końcowego opisu dobrych praktyk. Konieczne okazało się także przeprowadzenie dodatkowych wizyt w wybranych sądach, w następstwie czego zespół przygotował 
końcowe opisy koncepcji dobrych praktyk (rys. 1, etapy 9-10). Opisy miały stanowić podstawę oceny i wyboru praktyk przez prezesów oraz posłużyć firmie wdrożeniowej do ustalenia planu wdrożenia.

Ostatecznie w zestawie koncepcji dobrych praktyk znalazły się następujące praktyki:

- elektroniczny nakaz doprowadzenia,

- informatyczne narzędzia komunikacji wewnętrznej,

- informatyczny system rezerwacji zasobów,

- kontrola zabezpieczeń stanowisk i urządzeń komputerowych z wykorzystaniem list audytowych,

- zarządzanie aktami sądowymi w postaci cyfrowej,

- zarządzanie zasobami i usługami informatycznymi.

Ich krótką charakterystykę zawiera tabela 8.

Tabela 8. Charakterystyka koncepcji dobrych praktyk informatycznych

\begin{tabular}{|l|l|}
\hline \multicolumn{1}{|c|}{ Dobra praktyka } & \multicolumn{1}{c|}{ Charakterystyka } \\
\hline $\begin{array}{l}\text { Elektroniczny nakaz } \\
\text { doprowadzenia }\end{array}$ & $\begin{array}{l}\text { Cel: wdrożenie narzędzi do elektronicznej wymiany danych dotyczących } \\
\text { zleceń doprowadzeń oskarżonych i świadków do sądów, realizowanych } \\
\text { przez jednostki policji. Istotą dobrej praktyki jest zastąpienie korespon- } \\
\text { dencji papierowej elektroniczną wymianą danych pomiędzy systemami } \\
\text { informatycznymi stron z wykorzystaniem ustalonego formatu EDI (opar- } \\
\text { tego na XML) oraz szyfrowanego tunelu sieciowego. } \\
\text { Korzyści: zmniejszenie kosztu przesłania informacji, pracochłonności } \\
\text { procesu oraz skrócenie czasu wymiany informacji. }\end{array}$ \\
\hline $\begin{array}{l}\text { Informatyczne narzę- } \\
\text { dzia komunikacji } \\
\text { wewnętrznej }\end{array}$ & $\begin{array}{l}\text { Cel: polepszenie jakości i szybkości komunikacji pomiędzy pracowni- } \\
\text { kami sądu dzięki wprowadzeniu elektronicznej platformy komunikacji } \\
\text { wewnętrznej. Platforma umożliwiałaby zastąpienie obiegu informacji za } \\
\text { pomocą dokumentów papierowych ich formą elektroniczną przesyłaną } \\
\text { jako treść listów elektronicznych, ich załączników lub komunikatów bez- } \\
\text { pośrednich. Drugim obszarem zastosowania platformy będzie tworzenie } \\
\text { elektronicznych archiwów danych (pism, zarządzeń, procedur itd.). } \\
\text { Korzyści: podniesienia sprawności obiegu informacji oraz zmniejszenia } \\
\text { kosztów całego procesu. }\end{array}$ \\
\hline $\begin{array}{l}\text { Zarządzanie aktami } \\
\text { sądowymi w postaci } \\
\text { cyfrowej }\end{array}$ & $\begin{array}{l}\text { Cel: opracowanie i wdrożenie systemu klasy Document Management } \\
\text { System (DMS) służącego do zarządzania aktami sądowymi w postaci } \\
\text { cyfrowej. Istotą dobrej praktyki jest stworzenie systemu skanowania akt } \\
\text { i rozpoznawania zawartych w nich treści (wykorzystanie technologii } \\
\text { OCR), opracowanie rozwiązań pozwalających na przyjmowanie do akt } \\
\text { dokumentów elektronicznych, opracowanie systemu przechowywania } \\
\text { i udostępniania cyfrowych akt. } \\
\text { Korzyści: umożliwienie uzyskania łatwego i równoczesnego dostępu do } \\
\text { akt, zminimalizowanie ryzyka utraty, uszkodzenia i modyfikacji akt oraz } \\
\text { zmniejszenie kosztów obsługi akt papierowych. }\end{array}$ \\
\hline
\end{tabular}


cd. tabeli 8

\begin{tabular}{|l|l|}
\hline \multicolumn{1}{|c|}{ Dobra praktyka } & \multicolumn{1}{c|}{ Charakterystyka } \\
\hline $\begin{array}{l}\text { Informatyczny } \\
\text { system rezerwacji } \\
\text { zasobów }\end{array}$ & $\begin{array}{l}\text { Cel: wdrożenie wspomaganych informatycznie narzędzi organizacyjnych } \\
\text { w obszarze zarządzania zasobami niezbędnymi do realizacji działal- } \\
\text { ności orzeczniczej i administracyjnej sądów. Istotą dobrej praktyki jest } \\
\text { zarządzanie zasobami organizacyjnymi, materialnymi oraz osobowymi } \\
\text { w sposób scentralizowany w jednolitym systemie informatycznym. } \\
\text { Korzyści: usprawnienie procesu zarządzania zasobami oraz możliwość } \\
\text { optymalizacji wykorzystania i kosztów eksploatacji zasobów. }\end{array}$ \\
\hline $\begin{array}{l}\text { Kontrola zabez- } \\
\text { pieczeń stanowisk } \\
\text { i urządzeń kompute- } \\
\text { rowych z wykorzy- } \\
\text { staniem list audyto- } \\
\text { wych }\end{array}$ & $\begin{array}{l}\text { Cel: zwiększenie poziomu bezpieczeństwa systemów informatycznych } \\
\text { sądu. Istotą dobrej praktyki jest przeprowadzanie kontroli zabezpieczeń } \\
\text { stanowisk i urządzeń komputerowych przy wykorzystaniu metody list } \\
\text { audytowych. } \\
\text { Korzyści: zwiększenie bezpieczeństwa SI, identyfikacja mocnych i sła- } \\
\text { bych stron zabezpieczeń systemu, poprawa funkcjonowania SI, dostoso- } \\
\text { wanie funkcjonowania i zabezpieczania SI do przepisów prawa i norm } \\
\text { ISO, zwiększenie świadomości pracowników na temat zagrożeń oraz } \\
\text { zwiększenie ich motywacji do przestrzegania zasad bezpieczeństwa. }\end{array}$ \\
\hline $\begin{array}{l}\text { Zarządzanie zaso- } \\
\text { bami i usługami } \\
\text { informatycznymi }\end{array}$ & $\begin{array}{l}\text { Cel: wdrożenie zasad skutecznego i efektywnego zarządzania sferą } \\
\text { informatyczną sądu. Istotą dobrej praktyki jest zastosowanie w sądach } \\
\text { tzw. informatycznego modelu usługowego wynikającego z koncepcji IT } \\
\text { Service Management, co oznacza wprowadzenie pojęcia usługi informa- } \\
\text { tycznej, czyli potrzeby organizacyjnej zaspokajanej przez sferę informa- } \\
\text { tyczną. } \\
\text { Korzyści: lepsze dopasowanie usług informatycznych do potrzeb sądu, } \\
\text { optymalizacja i planowanie wydatków sfery informatycznej, zwiększona } \\
\text { skuteczność i efektywność pracy wynikająca z jakości i lepszego dopa- } \\
\text { sowania usług informatycznych do potrzeb użytkowników, efektywne } \\
\text { zarządzanie umożliwiające nadążanie za tempem zmian, zwiększone } \\
\text { zadowolenie użytkowników, lepszy wizerunek sądu. }\end{array}$ \\
\hline
\end{tabular}

Źródło: opracowanie własne.

Opisy dobrych praktyk zostały rozesłane do wszystkich sądów w celu umożliwienia zapoznania się z nimi przed ostatecznym wyborem (rys. 1, etap 11) oraz do firmy wdrożeniowej w celu przygotowania planów wdrożenia. Prezesi sądów dokonali oceny ich przydatności dla swojego sądu, a podczas kolejnego spotkania odbyła się dyskusja w grupach roboczych, w której uczestniczyli prezesi i dyrektorzy sądów, eksperci oraz przedstawiciele firmy wdrożeniowej. Każdy z prezesów miał możliwość zadawania pytań dotyczących szczegółów dobrej praktyki i sposobu jej wdrożenia. Po spotkaniu prezesi wybrali ostateczny zestaw dobrych praktyk (rys. 1, etap 12). Każdy z nich miał za zadanie wybrać 15 z 20 zaproponowanych dobrych praktyk. Wybór 6 praktyk informatycznych przedstawia tabela 9. 
Tabela 9. Wybór pilotażowych praktyk informatycznych dokonany przez prezesów 30 sądów

\begin{tabular}{|c|c|c|c|c|}
\hline \multirow{2}{*}{ Dobra praktyka } & \multicolumn{4}{|c|}{ Sądy } \\
\hline & rejonowe & okręgowe & apelacyjne & ogółem \\
\hline Elektroniczny nakaz doprowadzenia & 8 & 4 & 0 & 12 \\
\hline $\begin{array}{l}\text { Informatyczne narzędzia komunikacji } \\
\text { wewnętrznej }\end{array}$ & 19 & 6 & 1 & 26 \\
\hline $\begin{array}{l}\text { Zarządzanie aktami sądowymi w postaci } \\
\text { cyfrowej }\end{array}$ & 5 & 6 & 0 & 11 \\
\hline Informatyczny system rezerwacji zasobów & 8 & 6 & 1 & 15 \\
\hline $\begin{array}{l}\text { Kontrola zabezpieczeń stanowisk i urządzeń } \\
\text { komputerowych z wykorzystaniem list audy- } \\
\text { towych }\end{array}$ & 12 & 3 & 1 & 16 \\
\hline $\begin{array}{l}\text { Zarządzanie zasobami i usługami informa- } \\
\text { tycznymi }\end{array}$ & 16 & 6 & 1 & 23 \\
\hline
\end{tabular}

Źródło: opracowanie własne.

Po wyborze praktyk konieczne było opracowanie planów ich wdrożenia w poszczególnych sądach. Przedstawiciele firmy wdrożeniowej w obecności ekspertów dyskutowali i omawiali koncepcje ich wdrożenia, a następnie opracowali harmonogram. Na tym etapie nastąpiły jeszcze pewne zmiany dotyczące wyboru praktyk przez sądy (rys. 1, etap 12-13) - ostateczny wybór praktyk informatycznych przedstawia tabela 10.

Wdrożenie praktyk w sądach (tzw. pilotaż podstawowy) trwało od czerwca 2013 r. do końca października 2014 r. Podczas wdrażania dobrych praktyk przez firmę wdrożeniową grupa ekspertów pełniła funkcje doradcze. Służyła pomocą przy wyjaśnianiu i rozwiązywaniu problemów, które pojawiły się podczas wdrożenia, oraz była gotowa do dostosowywania dobrych praktyk do specyficznych wymagań poszczególnych sądów (rys. 1, etap 14). W tym czasie KSSiP podjęła decyzję o zwiększeniu liczby sądów, w których wdrażane będą dobre praktyki. Przeprowadzone zostało wdrożenie uzupełniające (tzw. pilotaż uzupełniający) w kolejnych 30 sądach. Trwało ono od maja do listopada 2014 r. Liczba i rodzaj praktyk informatycznych, które miały do wyboru sądy, nie uległa zmianie, natomiast opracowane zostały dodatkowe 4 praktyki z zakresu orzecznictwa, w rezultacie czego sądy we wdrożeniu uzupełniającym miały do wyboru 15 z 24 praktyk. Zbiorcze zestawienie wdrożenia praktyk informatycznych zawiera tabela 10.

Analizując informacje o wdrożeniu, należy podkreślić - na co zwrócono również uwagę w raporcie (Badanie ewaluacyjne... 2015) - że praktyki informatyczne (oprócz praktyk dotyczących komunikacji z interesantami i nowoczesnego 
zarządzania zasobami ludzkimi) cieszyły się największym zainteresowaniem we wdrożeniu podstawowym. Także w obu wdrożeniach spośród 24 praktyk do grupy 15 najczęściej wybieranych należało 5 praktyk informatycznych. Na przykład druga pod względem popularności była praktyka „Informatyczne narzędzia komunikacji wewnętrznej” wybrana i wdrożona w 42 sądach. Spośród praktyk informatycznych z powodu wysokich kosztów najrzadziej wdrażano praktykę „Zarządzanie aktami sądowymi w postaci cyfrowej”.

Tabela 10. Wdrożenie praktyk informatycznych w 30 sądach pilotażowych oraz w 30 sądach dodatkowych

\begin{tabular}{|l|c|c|c|}
\hline \multicolumn{1}{|c|}{ Dobra praktyka } & $\begin{array}{c}\text { Liczba sądów } \\
\text { - pilotaż } \\
\text { podstawowy }\end{array}$ & $\begin{array}{c}\text { Liczba sądów } \\
\text { dodatkowych } \\
- \text { pilotaż } \\
\text { uzupełniający }\end{array}$ & Sądy ogółem \\
\hline Elektroniczny nakaz doprowadzenia & 6 & 11 & 17 \\
\hline $\begin{array}{l}\text { Informatyczne narzędzia komunikacji } \\
\text { wewnętrznej }\end{array}$ & 25 & 17 & 42 \\
\hline $\begin{array}{l}\text { Zarządzanie aktami sądowymi w postaci } \\
\text { cyfrowej }\end{array}$ & 6 & 1 & 7 \\
\hline $\begin{array}{l}\text { Informatyczny system rezerwacji zasobów } \\
\text { Kontrola zabezpieczeń stanowisk i urządzeń } \\
\text { komputerowych z wykorzystaniem list audy- } \\
\text { towych }\end{array}$ & 13 & 4 & 17 \\
\hline $\begin{array}{l}\text { Zarządzanie zasobami i usługami informatycz- } \\
\text { nymi }\end{array}$ & 22 & 1 & 23 \\
\hline
\end{tabular}

Źródło: opracowanie własne na podstawie (Badanie ewaluacyjne... 2015).

Harmonogram wdrożenia oraz poziom zaawansowania prac w poszczególnych sądach przedstawiono w opracowaniu (Raport całościowy... 2014). Podsumowanie projektu wraz z uwzględnieniem szkoleń zawiera (Raport końcowy... 2015). Opis sposobu wdrażania praktyk, pozytywne efekty wynikające z ich wdrożenia oraz trudności podczas wdrażania zaprezentowano w raporcie (Badanie ewaluacyjne... 2015). Znajduje się tam także opis sytuacji wybranych sądów w ujęciu: „stan przed wdrożeniem dobrej praktyki” oraz „wprowadzone usprawnienia”. Ponadto dla każdej praktyki przedstawione są jej „zalety i ograniczenia” oraz „ocena efektów i procesu wdrażania”. 


\section{Podsumowanie}

Omawiany projekt w swoich założeniach i późniejszych efektach bardzo ściśle wpisuje się w założenia strategii lizbońskiej, akcentującej wykorzystanie potencjału naukowego w budowaniu przewagi gospodarczej i społecznej państw UE. Założenia samego projektu bardzo precyzyjnie wskazały na poszukiwanie dobrych praktyk z obszarów biznesowych, które można przenieść na sferę zarządzania sądami powszechnymi. Autorzy niniejszej pracy - eksperci w omawianym projekcie - jako pracownicy naukowi z obszaru zarządzania i informatyki wskazali metody i praktyki wdrażane w przedsiębiorstwach komercyjnych, które z podobną efektywnością pomogą skutecznie zarządzać organizacją pracy, motywacją pracowników oraz sferą IT w sądach różnych szczebli. Na pozytywną ocenę zasługuje również fakt, że dobre praktyki pochodziły także z samych sądów objętych pilotażem. Świadczy to o dodatkowej funkcji projektu jako platformy wymiany wiedzy pomiędzy sądami różnych szczebli. Przedstawione rezultaty omawianego projektu pozwalają na rekomendację realizacji podobnych przedsięwzięć w dalszych etapach reformy polskiego sądownictwa.

\section{Literatura}

Andrade A., Joia L.A. (2010), Organizational Structure and ICT Strategies in the Brazilian Justice, Proceedings of the 4th International Conference on Theory and Practice of Electronic Governance, ICEGOV'10, October 25-28, Beijing, China.

Badanie ewaluacyjne pilotażu wdrażania dobrego zarzqdzania jednostkami wymiaru sprawiedliwości w ramach projektu „PWP Edukacja w dziedzinie zarzqdzania czasem i kosztami postępowań sq̨dowych - case management”. Raport końcowy (2015), ASM - Centrum Badań i Analiz Rynku, Kutno.

Baskerville R.L. (1999), Investigating Information Systems with Action Research, Communications of the Association for Information Systems, vol. 2, Article 19, http://aisel. aisnet.org/cais/vol2/iss1/19 (data dostępu: 15.09.2014).

Baskerville R.L., Wood-Harper A.T. (1996), A Critical Perspective on Action Research as a Method for Information Systems Research, ,Journal of Information Technology”, vol. 11, nr 3, https://doi.org/10.1080/026839696345289.

Bueno T.C.D., Bortolon A., Hoeschl H.C., Mattos E.S., Santos C.S., Theiss I. (2003), Using RBC to Classify Judicial Petitions on e-Court, Proceedings of the 9th international conference on Artificial intelligence and law, ICAIL '03, June 24-28, Edinburgh, Scotland, UK.

COBIT 4.1. Metodyka, Cele kontrolne, Wytyczne zarzqdzania, Modele dojrzałości (2010), IT Governance Institute, Stowarzyszenie Audytu, Bezpieczeństwa i Kontroli Systemów Informacyjnych ISACA, Warszawa.

Cole M., Avison D. (2007), The Potential of Hermeneutics in Information Systems Research, „European Journal of Information Systems”, vol. 16, nr 6, https://doi.org/10.1057/palgrave.ejis.3000725. 
Czapracka A., Rostkowski T., Witkowski M. (2015), Wdrażanie zmian w sqdownictwie, Oficyna Wydawnicza Rozwoju Kapitału Ludzkiego, Warszawa.

Davison R.M., Martinsons M.G., Kock N. (2004), Principles of Canonical Action Research, „Information Systems Journal”, vol. 14, nr 1, https://doi.org/10.1111/j.1365-2575. 2004.00162.x.

Davison R.M., Martinsons M.G., Ou C.X.J. (2012), The Roles of Theory in Canonical Action Research, „MIS Quarterly”, vol. 36, nr 3, https://doi.org/10.2307/41703480.

Działanie 5.3 „Wsparcie na rzecz realizacji strategii lizbońskiej” (2016), http://www. wyszukiwarkafunduszy.pl/strona/wsparcie-na-rzecz-realizacji-strategii-lizbonskiej (data dostępu: 12.12.2016).

Gołaczyński J. (2009), Informatyzacja postępowania sq̨dowego w prawie polskim i prawach wybranych państw, Wolters Kluwer Polska, Warszawa.

Gorham U. (2012). State Courts, e-filing, and Diffusion of Innovation: A Proposed Framework of Analysis, Proceedings of the 13th Annual International Conference on Digital Government Research, dg.o '12, June 04-07, College Park, MD, USA.

Grabowski M. (2015), ITSM Good Practice Diffusion: A Case Study of Polish Judiciary (w:) Contemporary Issues in Economics. Business and Management - EBM 2014, red. R. Radosavljevic, Conference Proceedings, Kragujevac, Serbia.

Grabowski M., Madej J., Trąbka J. (2014a), IT/IS Good Practices for Polish Judiciary (w:) Knowledge, Economy, Society: Contemporary Tools of Organizational Resources Management, red. P. Lula, T. Rojek, Foundation of the Cracow University of Economics, Kraków.

Grabowski M., Madej J., Trąbka J. (2014b), Using IT to Improve Efficiency of Polish Courts, 20th Americas Conference on Information Systems (AMCIS 2014) „Smart Sustainability: The Information Systems Opportunity", Savannah, USA, August 7-9, Curran Associates, Inc., Association for Information Systems (AIS), New York.

Informatyzacja postępowania cywilnego. Teoria i praktyka (2016), red. K. Flaga-Gieruszyńska, J. Gołaczyński, D. Szostek, Seria Monografie Prawnicze, Wydawnictwo C.H. Beck, Warszawa.

Luzuriaga, J.M., Cechich, A. (2011). Electronic Notification of Court Documents: A Case Study, Proceedings of the 5th International Conference on Theory and Practice of Electronic Governance, ICEGOV '11, September 26-28, Tallinn, Estonia.

Materiały przetargowe „PWP Edukacja w dziedzinie zarządzania czasem i kosztami postępowań sądowych - case management" (2013), Krajowa Szkoła Sądownictwa i Prokuratury, ogłoszenie przetargu 6.12.2013, https://www.kssip.gov.pl/node/1799 (data dostępu: 12.12.2016).

Paulk M.C., Weber C.V., Curtis B., Chrissis M.B. (1993), Capability Maturity Model for Software (Version 1.1), Technical Report CMU/SEI-93-TR-024 ESC-TR-93-177, February, Software Engineering Institute, Carnegie Mellon University, Pittsburgh, PA, https://resources.sei.cmu.edu/asset_files/TechnicalReport/1993_005_001_16211.pdf (data dostępu: 13.04. 2018).

Raport całościowy z wdrożenia za okres od 1 grudnia 2013 r. do 24 października 2014 r. (2014), oprac. WYG International, WYG Consulting, WYG PSDB, Uniwersytet Ekonomiczny w Krakowie, Instytut Allerhanda na zlecenie Krajowej Szkoły Sądownictwa i Prokuratury, http://www.efs2007-2013.gov.pl/Dokumenty (data dostępu: grudzień 2016). 
Raport końcowy z badania ewaluacyjnego Projektu: „PWP Edukacja w dziedzinie zarzqdzania czasem i kosztami postępowań sqdowych - case management" realizowanego przez Krajowq Szkołę Sqdownictwa i Prokuratury, wspótfinansowanego przez Unię Europejskq w ramach Programu Operacyjnego Kapitat Ludzki 2007-2013 Priorytet V „Dobre rzqdzenie”, działanie 5.3 „Wsparcie na rzecz Strategii Lizbońskiej” (2015), oprac. EU-Consult Sp. z o.o. na zlecenie Krajowej Rady Sądownictwa i Prokuratury, http://www.efs2007-2013.gov.pl/Dokumenty (data dostępu: grudzień 2016).

Rojewski M. (2012), Rola informatyzacji w rozwoju sprawnego sqdownictwa i administracji na przykładzie Krajowego Rejestru Sqdowego i ksiag wieczystych, „Biuletyn Stowarzyszenia Absolwentów i Przyjaciół Wydziału Prawa Katolickiego Uniwersytetu Lubelskiego", nr 8.

Vries E. (2007), Rigorously Relevant Action Research in Information Systems, University of Amsterdam, The Netherlands, Sprouts: Working Papers on Information Systems, 7(4), http://sprouts.aisnet.org/7-4 (data dostępu: 19.04.2014).

\section{Designing and Implementing IT Good Practices for Common Courts} (Abstract)

The paper presents a process for conceptualising and deploying IT (information technology) good practices formulated during the implementation of the „Education in the area of time management and cost management of judicial proceedings - case management" project (a part of Poland's Human Capital Programme). This project was one of the components supporting the reform of the Polish judiciary and was aimed at increasing the efficiency of the judicial system by lowering costs and increasing employee skills. The paper describes all of the project phases the authors participated in their capacity as both experts and researchers. These included learning about the auto-diagnosis of 30 pilot courts, through conducting on-site visits in chosen courts, to formulating the final deployment concepts of six IT good practices implemented in a selected pool of 60 courts.

Keywords: information technology, information system, IT good practices, judiciary, courts, judicial system efficiency. 